Journal of Energy and
Environmental Sustainability
Journal homepage : www.jees.in

\title{
Studies on Temperature Variation in Automotive Exhaust Thermoelectric Generator with Exhaust Pipe Length
}

\author{
Sarthak Naga, Surya Bharathi Thangavelu ${ }^{b}$, Gaurav Tripathi ${ }^{a}$, Atul Dhar ${ }^{a^{*}}$ and Arpan Gupta ${ }^{a}$ \\ a School of Engineering, Indian Institute of Technology, Mandi, Kamand-175 005, Himachal Pradesh, India \\ ${ }^{b}$ Department of Mechanical Engineering, SSN College of Engineering, Kalavakkam-603 110, Tamil Nadu, India
}

\section{A R T I C L E I N F O}

Received : 15 May 2017

Revised : 05 June 2017

Accepted : 09 June 2017

Keywords:

thermoelectric generators, automotive exhaust thermoelectric generator heat exchanger, internal combustion engine, waste heat recovery, CFD modelling

\begin{abstract}
A B S T R A C T
Thermoelectrictechnology has good potential for its application as automotive exhaust based thermoelectric generator (TEG). In this work, the temperature variation on the surface of the automotive exhaust thermoelectric generator (AETEG) heat exchanger has been studied.The surface of heat exchanger acts as base for applying TEG modules to recover waste heat from the exhaust. Experiments have been carried out by varying the distance of the AETEG heat exchanger from the engine exhaust side by increasing pipe's length. In addition to it, the load on the engine was also varied to study its effects. These experimental results have been validated by simulating the same cases in CFD solver Star CCM. The experimental results show good agreement with the computed results. Simulation and experiments, both reveal that the variation in length of the pipe has very little effect on the temperature distribution on AETEG, however increasing the load increases the temperature on AETEG due to the increase in exhaust temperature. The maximum voltage and power output was also estimated for a specific TEG module which came out to be $7.12 \mathrm{~V}$ and $15.58 \mathrm{~W}$ at $30 \%$ load condition.
\end{abstract}

(C) 2017 ISEES, All rights reserved

\section{Introduction}

Internal combustion engines run on fuels like petrol or diesel, which causes environmental hazard and pollution. To add to this, there has been a global energy crisis due to depleting reserves of fuels across the world [Kim et al., 2015; Kim et al., 2016]. The fuel consumption in India for the year 2014 was 3.8 million barrel per day, out of which $40 \%$ is consumed by transport sector [Birol, 2015]. Moving towards internal combustion engines, around $65-70 \%$ of the total energy is being wasted in the form of heat, either via hot exhaust air or by liquid coolant flowing through the engine [Champier, 2017]. All of the above stated factors have pushed towards waste heat recovery.

The major focus has been on recovering exhaust waste heat as $30 \%$ of the engine's energy is lost by exhaust heat [Baglione, 2007; Lu et al., 2013; Yang and Stabler, 2009]. Various researchers have been working on exhaust heat recovery (EHR) solutions. Wang et al.(2011) have shown thermal system using Rankine cycle with efficiency of nearly $30 \%$. Zhang et al. [2014] studied Organic Rankine cycle (ORC) and showed the efficiency of over 6\%. Ali and Chakraborty [2015] developed cabin air conditioning system using EHR with coefficient of performance (COP) being 0.39. All the above discussed are fluid based EHR approaches which are complex, low on reliability and adds up to the cost. Researchers have also been working on solid state based EHR approach which uses thermoelectric (TE) material to convert heat directly into electricity. It works on the principle of Seebeck effect [Martínez et al., 2010], which states that if the temperature gradient is applied between two dissimilar electrical conductors or semiconductors, voltage difference is produced between them. Hot exhaust gives the high temperature to the thermoelectric generator (TEG) from one side, whereas the coolant/ cooling water maintains the other side at a relatively lower temperature, which provides the temperature gradient across the TE module [Deng et al., 2014]. The major advantage of using TEG is low failure rate due to no moving components [Kim et al., 2016], but the low efficiency of TE modules is its drawback. Other aspect of TE module is the material. TE Modules made of alloys of Bismuth with Antimony and Selenium or Telluride is most common due to lower cost, however Lead based TEGs and SiliconGermanium alloy TEGs find its application in high temperature application and hence in EHR of automobiles [Biswas et al., 2012; Patil and Arakerimath, 2013; Ramade et al., 2014].

Due to the low efficiency of nearly $8 \%$ [Tripathi and Dhar, 2017], there is a need to improve the efficiency of the heat exchanger used to extract the heat of the exhaust and to optimize the positioning of the automotive exhaust thermoelectric generator in the exhaust line. Researchers have already worked to improve the efficiency of the heat exchanger by using baffles, varying internal pipe length in the flow stream, 
using efficient flow systems and much more [Hatami et al., 2014; Lu et al., 2013]. However, optimizing the position is one field which hasn't got much attention from the researchers. So this work focusses to explore the effect of the variation in position of AETEG unit in the exhaust line on its own performance.The main aim of this work was to define the position of the AETEG unit. The exhaust line of an automobile is quite long and consists of various components. In our work, we wanted to explore the effect of position of AETEG on the voltage produced. Finding the optimum position is important as very close placement with engine cylinder will cause damage to thermoelectric modules and far away placement results in reduced output power.

\section{Materials and Methods}

\subsection{Description of Experimental Setup:}

The experimental set-up was designed to study the effect of the positioning of AETEG heat exchanger unit in the exhaust line. Figure 1 shows the schematic diagram of the setup. The test was carried on Kirloskar TV-1 diesel engine. Table 1 shows the specifications of the test engine. Figure 2 (a) shows the heat exchanger for AETEG unit which was fabricated using aluminium sheet of thickness $3 \mathrm{~mm}$. It was a rectangular crosssection channel with dimensions of $210 \mathrm{~mm} \times 81 \mathrm{~mm} \times 34 \mathrm{~mm}$. It was mounted on the exhaust line. The temperature on different positions of this heat exchanger was measured using thermocouple wires. Figure 2 (b) shows the positions on which the temperature was measured whereas figure 2 (c) and (d) shows the temperature measurement setup. Another thermocouple was installed in the exhaust line to measure the exhaust air temperature at the inlet of the heat exchanger (see figure 2 (e)).

Table 1: Specifications of the test engine

\begin{tabular}{|l|l|}
\hline Cycle & 4 Stroke \\
\hline Cylinders & 1 \\
Swept Volume & $661 \mathrm{cc}$ \\
Stroke length & $0.11 \mathrm{~m}$ \\
Bore diameter & $0.0875 \mathrm{~m}$ \\
Speed & $1500 \mathrm{rpm}$ \\
Compression Ratio & $17.5: 1$ \\
Power & $5.2 \mathrm{~kW}$ \\
Loading Device & AC transient dynamometer \\
\hline
\end{tabular}

1. AETEG; 2. Variable exhaust length region;

3. Exhaust thermocouple; 4. Engine exhaust; 5 . Test engine;

6. Fuel tank; 7. Fuel line; 8. Control panel; 9. Dynamometer;

10. Temperature measuring points; 11 . Temperature displayer.

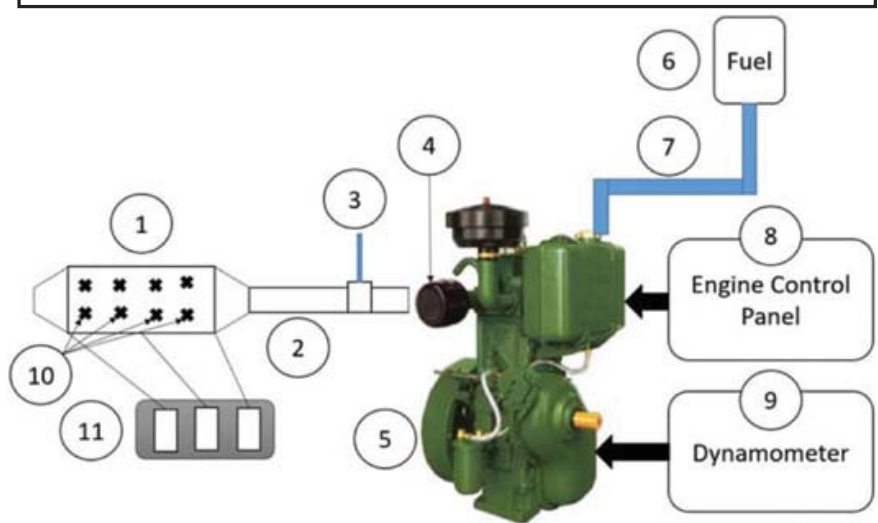

Figure 1 Schematic Diagram of Experimental Setup

\subsection{Engine Operation Points and Procedure:}

The engine was operated at 4 different loads, i.e. no load $(0 \%), 0.51$ $\mathrm{kW}(10 \%), 1.04 \mathrm{~kW}(20 \%)$ and $1.56 \mathrm{~kW}(30 \%)$. The position of the heat exchanger in the exhaust line was varied using the G.I. fittings. For each load, the distance from the engine exhaust outlet was varied in three steps; $140 \mathrm{~mm}, 210 \mathrm{~mm}$ and $280 \mathrm{~mm}$. Hence a total of 12 cases were formed.

\subsection{Simulation Approach:}

A model of AETEG heat exchanger was developed using Solid Works and the CFD and Heat Transfer simulations were carried using Star CCM software. The grid independence study was carried using 3 different mesh sizes and the mesh with optimized computation time and size was chosen. Figure 3 (a) and (b) shows the geometry and the meshing of the model. The three geometries were developed for three entry positions of 140 $\mathrm{mm}, 210 \mathrm{~mm}$ and $280 \mathrm{~mm}$. These three geometries were then simulated for four different loads, thus making a total of 12 cases in all. All the cases were run for three dimensional study. The material properties for aluminium was chosen from Star CCM database with density of $2702 \mathrm{~kg} / \mathrm{m}^{3}$, specific heat of $903 \mathrm{~J} / \mathrm{kg}-\mathrm{K}$ and thermal conductivity of $237 \mathrm{~W} / \mathrm{m}-\mathrm{K}$. The inlet

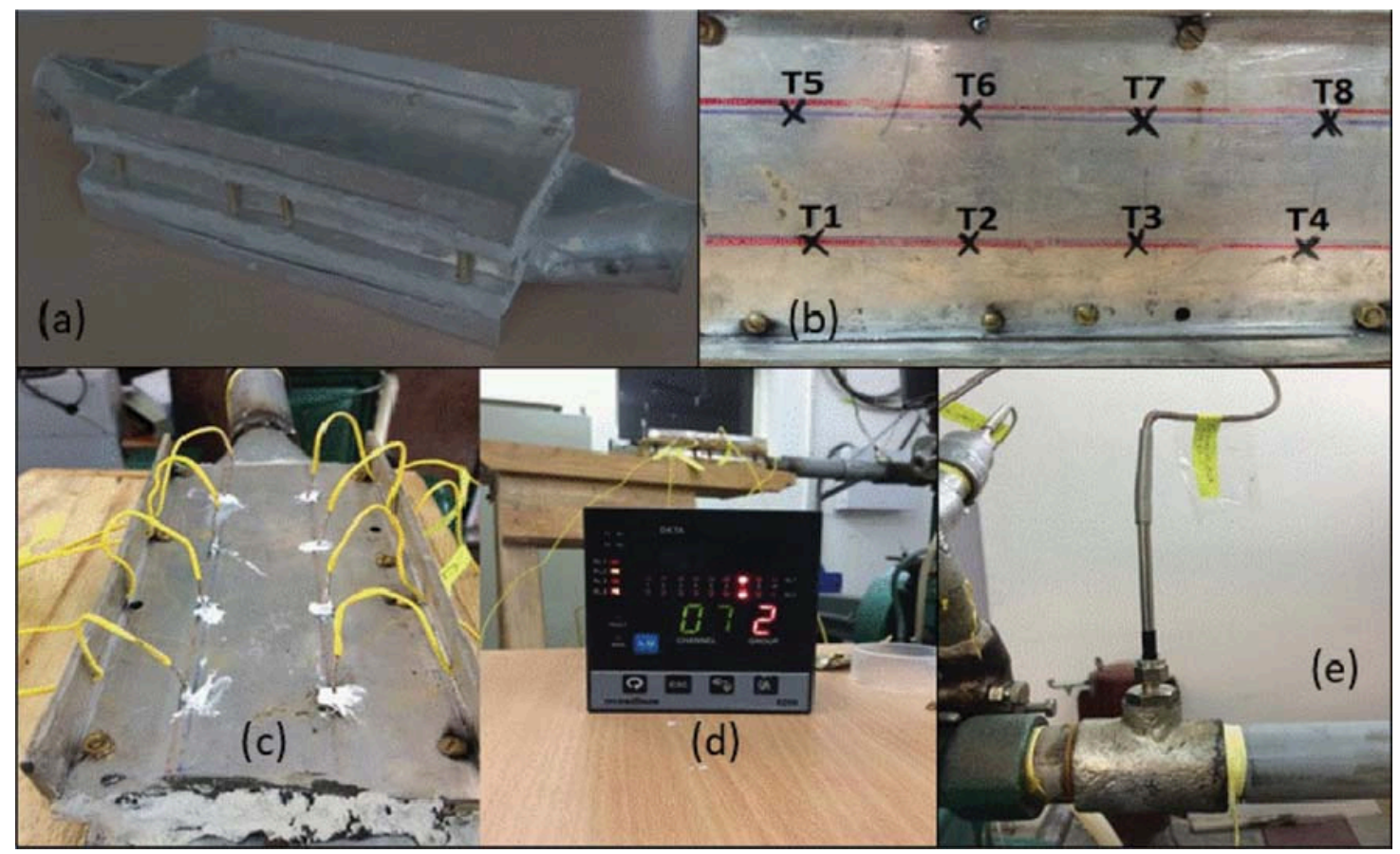

Figure 2 (a) AETEG Heat Exchanger; (b) Temperature Measuring Positions; (c) Thermocouple used to measure the temperatures;

(d) Temperature display; (e) Thermocouple to measure exhaust outlet temperature 


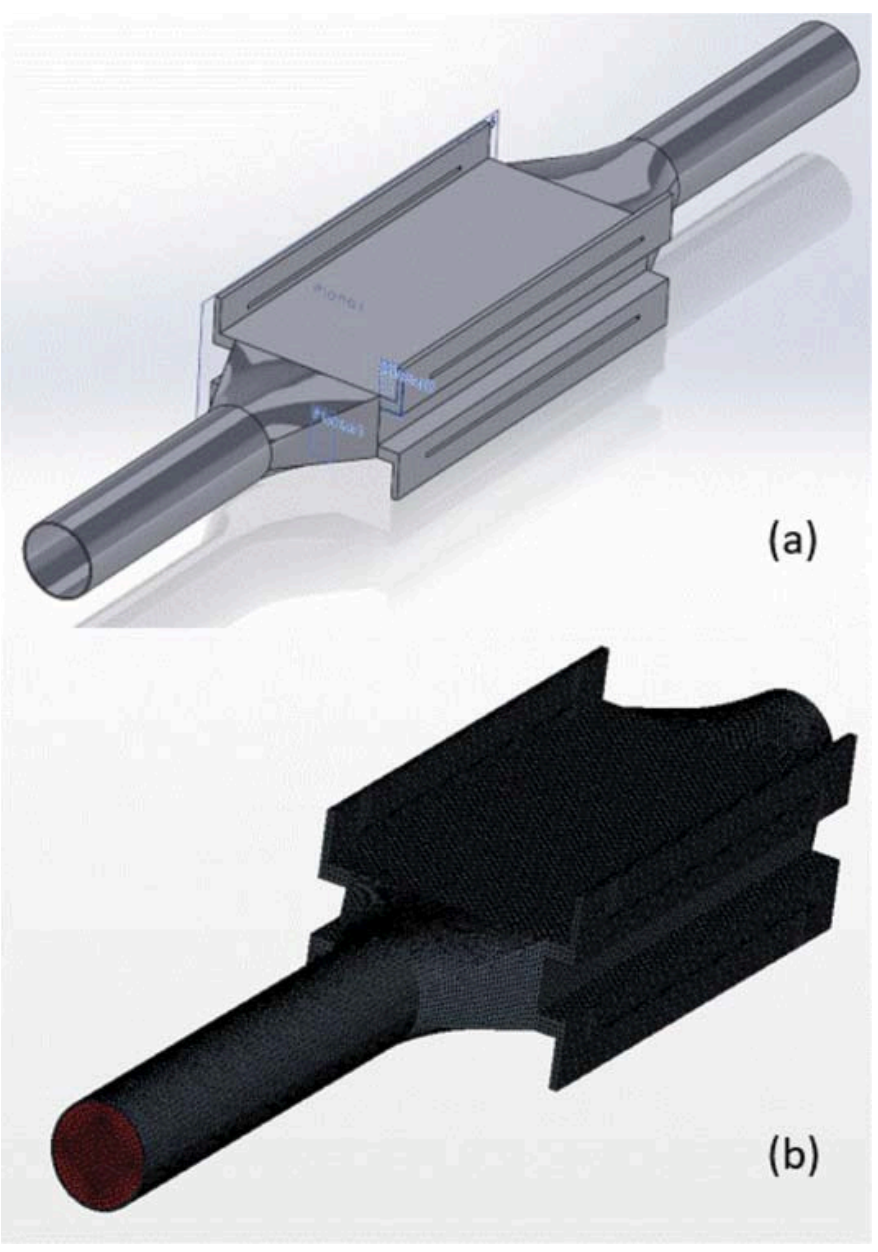

Figure 3 (a) Geometry of the model (Solid Works); (b)Sample Mesh(using Star CCM)

exhaust velocity wascalculated $9.2 \mathrm{~m} / \mathrm{s}$ whereas exhaust entry temperature input was given to the model using the thermocouple (see figure 2 (e)) readings from the experimental set-up. The surrounding of the AETEG heat exchanger were matched with ambient conditions with heat transfer co-efficient value of $17.5 \mathrm{~W} / \mathrm{m}^{2}-\mathrm{K}$. The case was solved for continuity, $\mathrm{x}$

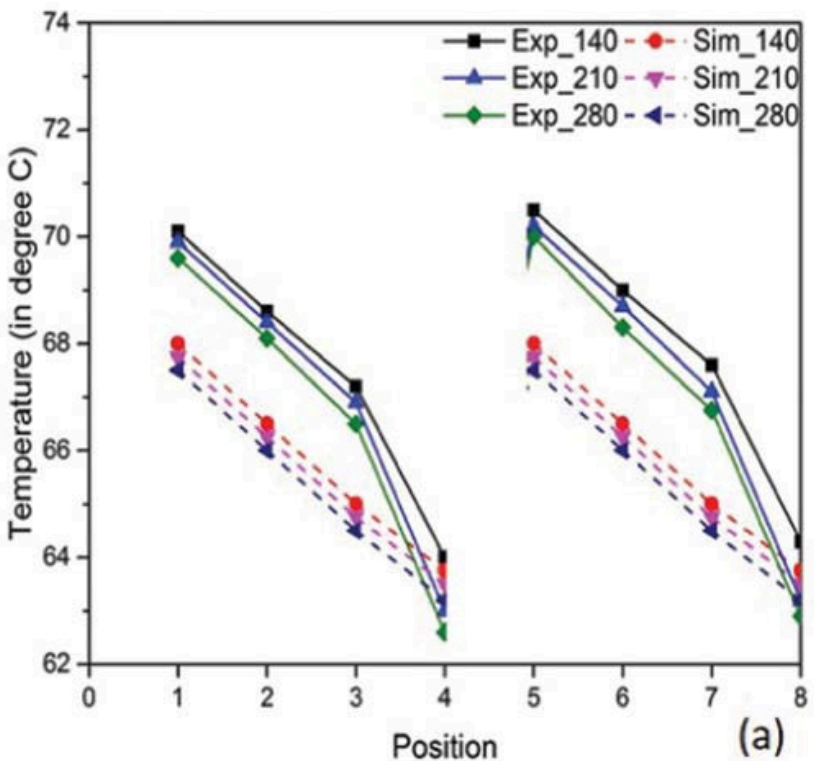

y $\mathrm{z}$ momentum and turbulent energy equation. The criteria for convergence was set at $1 \mathrm{e}-04$.

\subsection{Voltage Calculations Procedures:}

On the basis of temperature readings on the surface of heat exchanger, the voltage and the net power output was also estimated. The module used for the estimations was Hi-Z make 14HV TEG module which constitute of 126 couples. The specifications sheets are available on the URL [Hi-Z 14 HV Specifications]. On the basis of geometry of our heat exchanger and the dimensions of TEG module, a total of 4 modules can be mounted (one upstream and one downstream constitute a set and there can be two sets, ventral and dorsal side). Both the upstream modules are expected to generate same power and so is the case with downstream modules. Temperature points 1, 2, 5 and 6 will serve for upstream modules and points $3,4,7$ and 8 will serve for downstream modules. Due to the lack of the external cooling system, the temperature on the cooling side is expected to increase rapidly, which implies performance for shorter time duration. The net percentage of the heat recovered by the AETEG unit was also estimated based on input power given by the burnt fuel.

\section{Results and Discussion}

\subsection{Temperature on the heat exchanger surface:}

Table 2 shows the variation of exhaust temperatures with the load variations. As the load on the engine is increasing, the exhaust gas temperature is increasing. These values were also used as an input to the simulation models.

Table 2: Exhaust temperature value at test loads

\begin{tabular}{l|l|l|l|l}
\hline Length & $0 \mathrm{~kW}$ & $0.52 \mathrm{~kW}$ & $1.04 \mathrm{~kW}$ & $1.56 \mathrm{~kW}$ \\
\hline $140 \mathrm{~mm}$ & $136.2^{\circ} \mathrm{C}$ & $152.1^{\circ} \mathrm{C}$ & $189.7^{\circ} \mathrm{C}$ & $227.5^{\circ} \mathrm{C}$ \\
$210 \mathrm{~mm}$ & $136.5^{\circ} \mathrm{C}$ & $152.6^{\circ} \mathrm{C}$ & $190.2^{\circ} \mathrm{C}$ & $228.1^{\circ} \mathrm{C}$ \\
$280 \mathrm{~mm}$ & $136.6^{\circ} \mathrm{C}$ & $152.8^{\circ} \mathrm{C}$ & $190.4^{\circ} \mathrm{C}$ & $228.3^{\circ} \mathrm{C}$ \\
\hline
\end{tabular}

Figure 4 (a), (b), (c) and (d) shows the variation of temperature on the surface of the AETEG heat exchanger with variation in load. Each graph is plotted for fixed load condition and shows both simulation and experimental results. In figure 4 (a), as the length of the pipe is increasing, the temperature on the surface of heat exchanger is decreasing. However, the temperature decline is not very sharp and it is within $1^{\circ} \mathrm{C}$ decrease from $140 \mathrm{~mm}$ to $280 \mathrm{~mm}$. The temperature decrease can be explained as the length of the pipe is increasing, the interactions with the surrounding increases and more heat loss occurs before the heat exchanger. The temperature decline is very low because of high flow velocity and low interaction time between the walls and the gas. Same trends are visible for $10 \%, 20 \%$ and $30 \%$ loads (see figure 4 (b), (c) \& (d)). Figure 5(a), (b) and

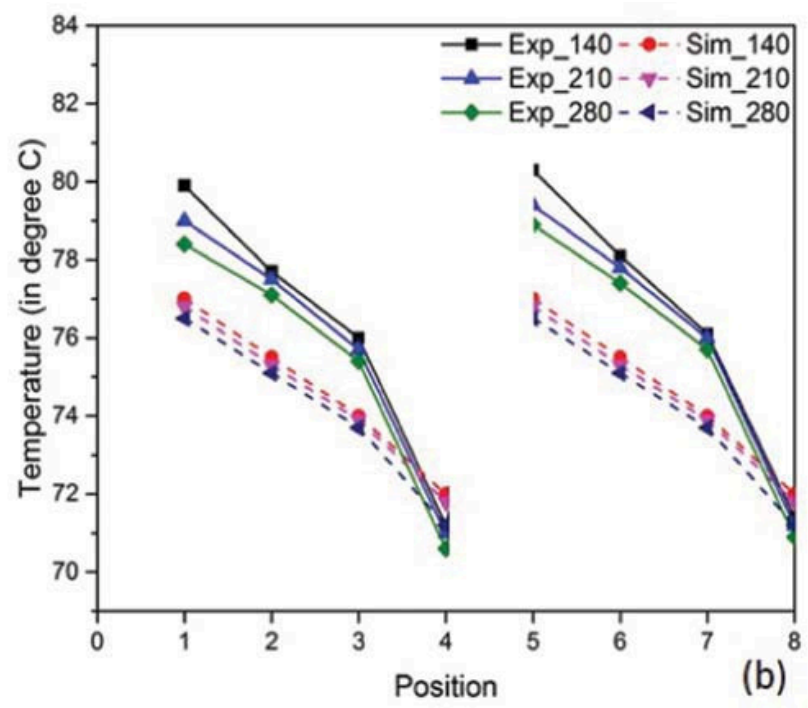

Figure 4 Variation of temperature on the surface of the AETEG heat exchanger at (a) $0 \% 10 a d$; (b) $10 \% 10 a d$; 

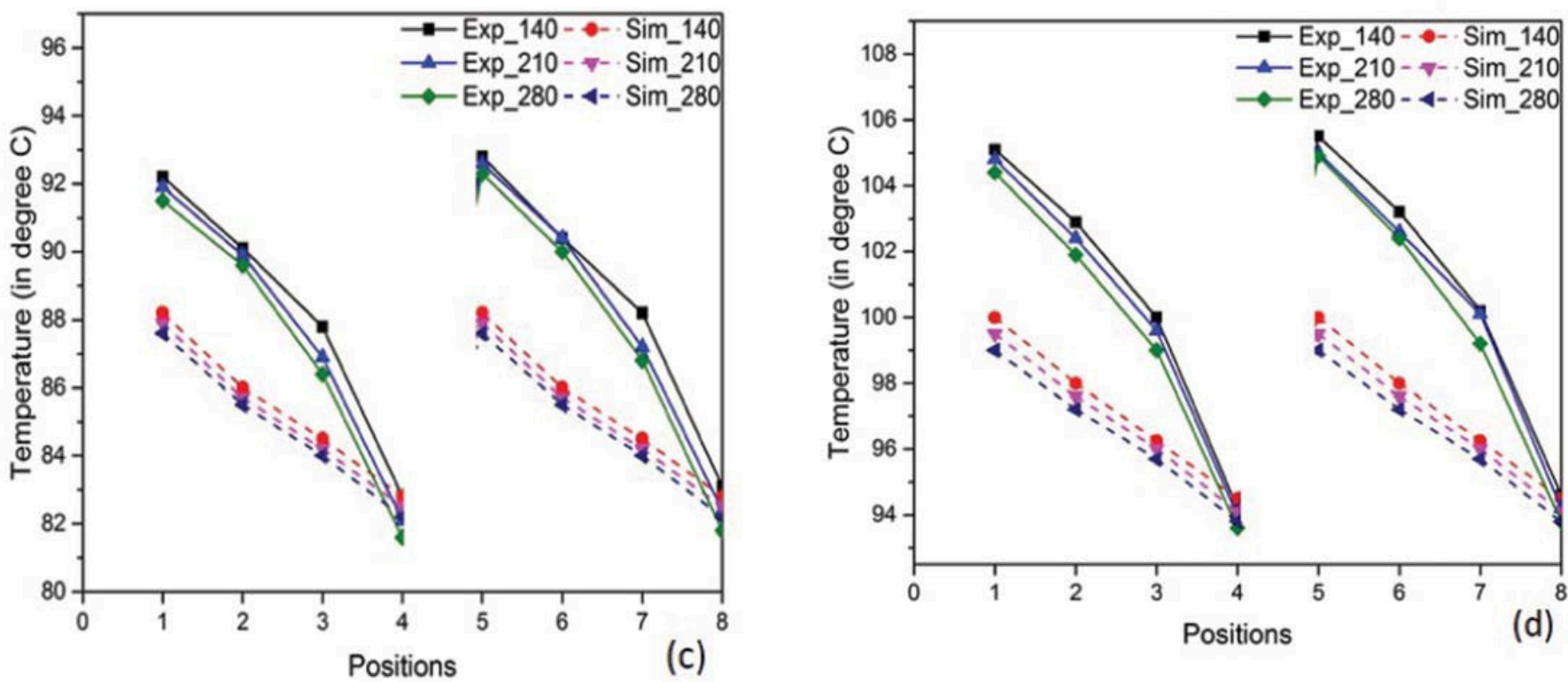

Figure 4 (c) 20\% load; (d) $30 \%$ load.

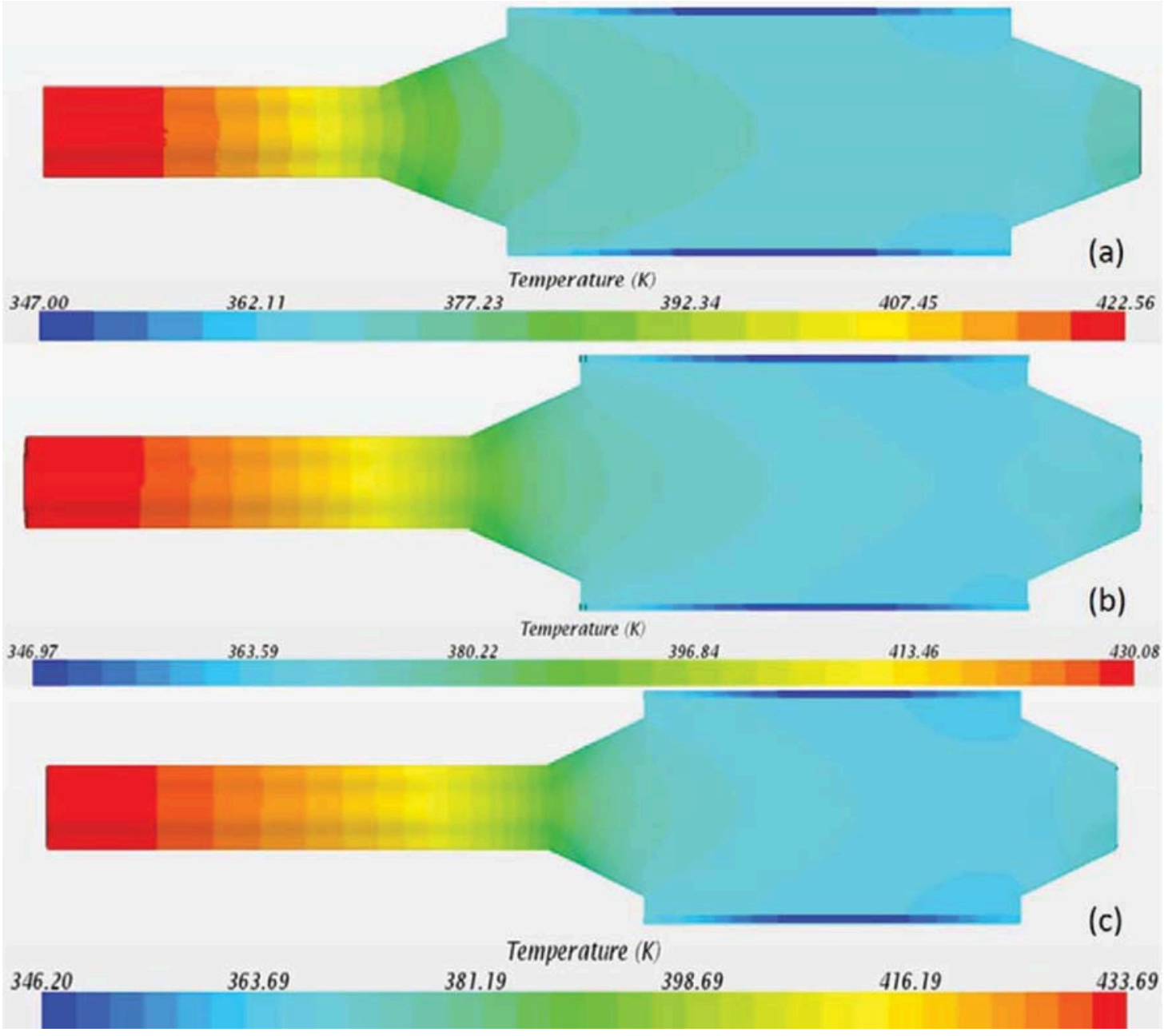

Figure 5: Temperature contour on the surface of AETEG heat exchanger for pipe length of (a) $140 \mathrm{~mm}$; (b) $210 \mathrm{~mm}$; (c) $280 \mathrm{~mm}$ 
(c) shows the temperature contours on the surface of heat exchanger with varying AETEG position which are obtained by simulations. The experimental results are in good agreement with the simulation results.

This shows that by varying the position from $140 \mathrm{~mm}$ to $280 \mathrm{~mm}$ from the reference, there is a minor change in temperature, which leads to the conclusion that this change will have a negligible effect on the performance of AETEG. However, the increase in load on the engine has led to increase in surface temperature, which is a function of AETEG performance. AETEG unit tends to perform well in high load conditions.

\subsection{Voltage output of AETEG:}

Table 3 shows the maximum achievable voltage from the AETEG on various load conditions. It is to be noted that varying the length has an effect of $0.08 \mathrm{~V}(\sim 0.5 \%$ of the maximum value), hence all the electrical output studies were done at $140 \mathrm{~mm}$ exhaust length, however the load was varied.Power generated from the AETEG unit was also calculated and plotted with variation in load, as shown in figure 6 . As the load on the engine is increasing, the voltage and power are increasing rapidly as electrical output is the direct function of temperature. Table 4 shows the percentage of energy recovered from the AETEG unit on the basis of the power of the engine.At 30\% load conditions, maximum efficiency along with maximum voltage and power output was obtained.

This shows that AETEG unit tends to give better performance at high load conditions due to increased exhaust temperature. The efficiency also improves marginally at high temperature. But the position of AETEG has very less or no effect on the electrical output.

Table 3: Estimated voltages based on temperature on the surface of heat exchanger

\begin{tabular}{|c|c|c|c|c|c|c|}
\hline \multirow[t]{2}{*}{ Load } & \multicolumn{2}{|c|}{ Avg. Hot side Temperature } & \multirow[t]{2}{*}{ Cold side temperature } & \multicolumn{2}{|c|}{ Delta T } & \multirow{2}{*}{$\begin{array}{l}\text { Maximum } \\
\text { Voltage (V) }\end{array}$} \\
\hline & Upstream & Downstream & & Upstream & Downstream & \\
\hline $\begin{array}{l}0 \% \\
10 \% \\
20 \% \\
30 \%\end{array}$ & $\begin{array}{c}69^{\circ} \mathrm{C} \\
80^{\circ} \mathrm{C} \\
92^{\circ} \mathrm{C} \\
103.5^{\circ} \mathrm{C}\end{array}$ & $\begin{array}{c}64^{\circ} \mathrm{C} \\
71^{\circ} \mathrm{C} \\
83^{\circ} \mathrm{C} \\
95.5^{\circ} \mathrm{C}\end{array}$ & $\begin{array}{l}14^{\circ} \mathrm{C} \\
14^{\circ} \mathrm{C} \\
14^{\circ} \mathrm{C} \\
14^{\circ} \mathrm{C}\end{array}$ & $\begin{array}{c}55^{\circ} \mathrm{C} \\
66^{\circ} \mathrm{C} \\
78^{\circ} \mathrm{C} \\
89.5^{\circ} \mathrm{C}\end{array}$ & $\begin{array}{l}50^{\circ} \mathrm{C} \\
57^{\circ} \mathrm{C} \\
69^{\circ} \mathrm{C} \\
81.5\end{array}$ & $\begin{array}{l}4.08 \\
4.96 \\
6.12 \\
7.12\end{array}$ \\
\hline
\end{tabular}

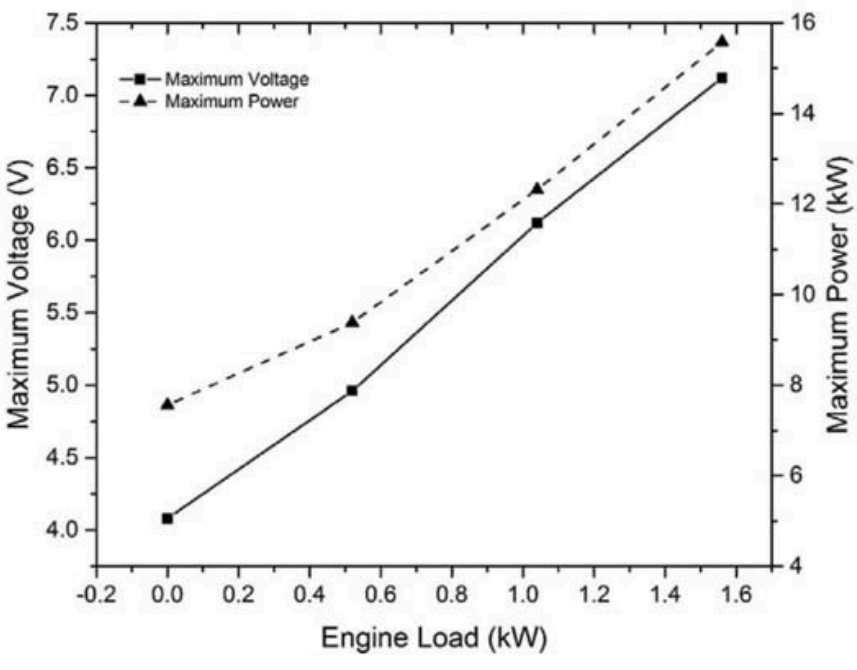

Figure 6: Variation of voltage and power generated with load

Table 4: Efficiency of the AETEG unit at various load

\begin{tabular}{l|c|c|c}
\hline Load & $\begin{array}{c}\text { Energy Recovered } \\
\text { from TEG (W) }\end{array}$ & $\begin{array}{c}\text { Energy Supplied } \\
\text { to Engine (W) }\end{array}$ & $\begin{array}{c}\text { Efficiency of } \\
\text { AETEG (\%age) }\end{array}$ \\
\hline $0 \%$ & 7.56 & 4181 & 0.18082 \\
$10 \%$ & 9.38 & 5017 & 0.18697 \\
$20 \%$ & 12.32 & 5733 & 0.21490 \\
$30 \%$ & 15.58 & 6450 & 0.24155 \\
\hline
\end{tabular}

\section{Conclusions}

The main aim was to study the effect of variation in length of exhaust pipe on the performance of AETEG unit. The position of AETEG unit was varied using different pipe lengths. The experimental results were then validated using simulations. The maximum voltage, power output and efficiency of the AETEG was also estimated. The major findings of this work are:

- Variation in length has very low effect on the temperature $\left(\sim 1^{\circ} \mathrm{C}\right)$ of the surface of heat exchanger.

- At $30 \%$ load conditions, the voltage, power and efficiency was $7.12 \mathrm{~V}$, $15.58 \mathrm{~W}$ and $0.24155 \%$ respectively due to high temperature. At lower loads, the electrical output was low.

- Hence the positioning of AETEG unit is not very critical in terms of standalone systems. The major deciding factor while setting the location of AETEG unit in automobile may be the space constraint in the exhaust line, as todays' automobiles are moving towards more compactness.

\section{References}

[1] Ali SM, Chakraborty A. Thermodynamic modelling and performance study of an engine waste heat driven adsorption cooling for automotive air-conditioning, Applied Thermal Engineering, 2015 Nov 5;90, 54-63.

[2] Baglione ML. Development of system analysis methodologies and tools for modeling and optimizing vehicle system efficiency (Doctoral dissertation, University of Michigan). 2017

[3] Birol F. India energy outlook. Paris: International Energy Agency. 2015.

[4] Biswas K, He J, Blum ID, Wu CI, Hogan TP, Seidman DN, Dravid VP, Kanatzidis MG. High-performance bulk thermoelectrics with all-scale hierarchical architectures, Nature, 2012 Sep 20;489(7416), 414-8.

[5] Champier D. Thermoelectric generators: A review of applications, Energy Conversion and Management, 2017 May 15;140, 167-181.

[6] Deng YD, Liu X, Chen S, Xing HB, Su CQ. Research on the compatibility of the cooling unit in an automotive exhaust-based thermoelectric generator and engine cooling system,Journal of Electronic Materials, 2014 Jun 1;43(6), 1815-1823.

[7] Hatami M, Ganji DD, Gorji-Bandpy M. A review of different heat exchangers designs for increasing the diesel exhaust waste heat recovery, Renewable and Sustainable Energy Reviews, 2014 Sep 30;37, 168-181.

[8] Hi-Z 14HV specification sheet. (URL: http://hi-z.com/wp-content/uploads/2016/ 08/HZ-14HV-Prelim-Spec-Sheet.pdf ). Accessed on 01-04-2017.

[9] Kim TY, Lee S, Kang K. Performance and emission characteristics of a highcompression-ratio diesel engine fueled with wood pyrolysis oil-butanol blended fuels, Energy, 2015 Dec 15;93, 2241-50.

[10] Kim TY, Negash AA, Cho G. Waste heat recovery of a diesel engine using a thermoelectric generator equipped with customized thermoelectric modules, Energy Conversion and Management, 2016 Sep 15;124, 280-286.

[11] Lu H, Wu T, Bai S, Xu K, Huang Y, Gao W, Yin X, Chen L. Experiment on thermal uniformity and pressure drop of exhaust heat exchanger for automotive thermoelectric generator, Energy, 2013 Jun 1;54, 372-377.

[12] Martínez A, Vián JG, Astrain D, Rodríguez A, Berrio I. Optimization of the heat exchangers of a thermoelectric generation system,Journal of electronic materials, 2010 Sep 1;39(9), 1463-8.

[13] Patil D, Arakerimath DR. A review of thermoelectric generator for waste heat recovery from engine exhaust, International Journal of Research in Aeronautical and Mechanical Engineering, 2013 Dec;1(8), 1-9.

[14] Ramade P, Patil P, Shelar M, Sameer C, Yadav S, Trimbake S. Automobile exhaust thermo-electric generator design \& performance analysis, International Journal of Emerging Technology and Advanced Engineering, 2014;4(5), 682-691.

[15] Tripathi G, Dhar A. Exhaust Heat Recovery Options for Diesel Locomotives, InLocomotives and Rail Road Transportation, 2017 Springer Singapore, 27-40.

[16] Wang T, Zhang Y, Peng Z, Shu G. A review of researches on thermal exhaust heat recovery with Rankine cycle, Renewable and Sustainable Energy Reviews, 2011 Aug 31;15(6), 2862-71.

[17] Yang J, Stabler FR. Automotive applications of thermoelectric materials, Journal of Electronic Materials, 2009 Jul 1;38(7), 1245-51.

[18] Zhang YQ, Wu YT, Xia GD, Ma CF, Ji WN, Liu SW, Yang K, Yang FB. Development and experimental study on organic Rankine cycle system with single-screw expander for waste heat recovery from exhaust of diesel engine, Energy, $2014 \mathrm{Dec}$ $1 ; 77,499-508$ 